\title{
The Perceptions of Graphic Design Concept on Students Study on Graphic Design
}

\author{
Sevtap Kanat \\ Correspondence: Sevtap Kanat, Faculty of Fine Arts and Design at Inonu University, Malatya Turkey. \\ Received: March 1, 2019 \\ Accepted: April 15, $2019 \quad$ Online Published: April 22, 2019 \\ doi:10.11114/jets.v7i5.4220 \\ URL: https://doi.org/10.11114/jets.v7i5.4220
}

\begin{abstract}
The purpose of this study is to examine the graphic design concept perceptions of university students who take graphic design education by using metaphors. The research was carried out with 160 students from the Department of Graphic Design at Inonu University, Hac1 Bayram Veli University and Necmettin Erbakan University. A total of 142 students (87 female and 55 male) were considered to be surveyed. The students were asked a personal information form and an open-ended question via a questionnaire prepared by qualitative research method. The analysis of the survey data was evaluated by the content analysis method from qualitative research techniques. According to the analysis, the participants created 96 metaphors. The most repeated metaphors for graphic design are; Dreaming (7), Universe (6) and Freedom (6).

The common characteristics of these metaphors produced by the participants were collected in eight sub-categories which are Effort /Labor dependent structure, Unlimited structure, Useful structure that facilitates, Multi-dimensional structure, Target-oriented structure, Changeable structure, Holistic structure, Uniform structure.

According to the result obtained in the study, there are different perceptions of the graphic design based on gender and grades.
\end{abstract}

Keywords: graphic design, graphic design student, metaphor, qualitative

\section{Introduction}

With the developments in the economic, social and technological fields in the 19th century, the use of graphic design in modern life has expanded. Especially in today's fast-paced consumption, graphic design products are faced (Gafuroğulları, 2014: 55). It has the power to inform and persuade people in many areas, ranging from signs used to prevent accidents in traffic, to the grafics showing the amount of cholesterol in people's food and to movie trailers (Twemlow, 2011: 6). Designers use graphic design in many areas such as logos, labels, newspaper advertisements, posters and magazines.

The word of "graphic" was first derived from the word "grafikos" or "graphein" which means writing and scraping in Greek. The word of "design" in Turkish is derived from "designation" in English. It means pointing to something in Turkish. This word has been used for printing on paper or leather by carving hard materials such as metal, wood or stone and then painting (Ağsakallı, 2014; Gafuroğulları, 2014; Çaydere, 2016).

Graphic design offers an economic, effective, informative and aesthetic way using typography, painting, photography, color, creative images and concepts (Ünalan, 2005; Uslu, 2017; Dokuzlar, 2015; Gafuroğulları, 2014; Becer, 2015) to solve a knowledge or a complex problem (Hembree, 2011: 11) is a flat surface that communicates or a two-dimensional visual expression language (Ketenci \& Bilgili, 2006; Arntson, 2012; Gafuroğulları, 2014; Ağsakall, 2014; Landa, 2014, Becer, 2015).

Graphic design that is as old as the history of humanity and a universal language gives the ability of visual literacy to the individual. The individual should be aware that graphic design must be an product of an aesthetic understanding, an artistic infrastructure and an intelligence. Therefore, lifelong learning is necessary for individuals who are capable of design to solve the problems they face and to produce practical solutions (Çaydere, 2016: 790).

Understanding graphic design does not require an educational level. Graphic images with high expressive power are a visual language easily understood by every human being in different cultures and societies. Nowadays, this language has increased the importance of graphic design as a communication tool between people (Ağsakallı, 2014: 6) and expanded its usage areas. 
Graphic design has a tradition of archiving, documenting, critically writing and publishing that consist of social, cultural and political information as in all other design areas (Triggs, 2011: 3). Because the artist of every period has transformed the expectations and aspirations of the people living in the same geography with their own ideas by using the technology of that period into a visual language. Thus, the artist took a task of documenting social phenomena from past to present (Dokuzlar, 2015; Uslu, 2017).

Today, the pressing foreman and cratfsman are replaced by graphic designers who produce with modern tools and equipment by the power of updated and contemporary interpretation. The graphic designer continues the lifelong education by following the new trends in society, developing technology, and the artistic, political and philosophical issues discussed (Mccarthy \& Almeida, 2002; 103). Graphic designer can communicate complex ideas to the society in a simple and effective manner in a smart and thought-provoking design (Hembree, 2011: 11). Moreover, the designer can find an aesthetic, safe, innovative and personalized approach on the studies (Ketenci \& Bilgili, 2006: 279).

In this study, it was aimed to find out the differentiation about the expression of the concept of "graphic desing" using the metaphors created by the students in the graphic design departments of the selected universities based on gender and grades. People use the metaphor through indirectly different analogies (Altıntaş, 2005:4), rather than directly to itself, to understand an abstract complex phenomenon (Persich, Steinemann, Fetterman \& Robinson, 2018), environment, object, event, or explanation (Pektaş \& Kıldan, 2009; Geçit \& Gençer, 2011). Shuell is the best phrase to express the power of metaphor. According to Shuell (1990) "If a picture is worth 1,000 words, a metaphor is worth 1,000 pictures! For a picture provides only a static image, while a metaphor provides a conceptual framework for thinking about something" (p.102).

\section{Methodology}

\subsection{Study Group}

The student study group of this research is composed of the department of Graphic Design, Faculty of Fine Arts and Design at Inonu University, department of Visual Communication, Faculty of Fine Arts at Hac1 Bayram Veli University, and department of Graphic Design, Faculty of Fine Arts at Necmettin Erbakan University. The questionnaries were applied to 160 students and 142 of these questionnaires were valid. The demographic characteristics of the students are given in Table 1.

Table 1. Demographic characteristics of the students

\begin{tabular}{c|l|l|l}
\hline Variable & Type & Frequency(n) & Percentage (\%) \\
\hline \multirow{3}{*}{ Gender } & Female & 87 & 61.26 \\
\cline { 2 - 4 } & Male & 55 & 38.74 \\
\cline { 2 - 4 } & Total & 142 & 100 \\
\hline \multirow{4}{*}{ Grades } & 1st Grade & 52 & 36.62 \\
\cline { 2 - 4 } & 2nd Grade & 31 & 21.84 \\
\cline { 2 - 4 } & 3rd Grade & 29 & 20.42 \\
\cline { 2 - 4 } & 4th Grade & 30 & 21.12 \\
\cline { 2 - 4 } & Total & $\mathbf{1 4 2}$ & $\mathbf{1 0 0}$ \\
\hline
\end{tabular}

\subsection{Data Collection Tool}

In order to collect data in the study, a semi-structured Questionnaire Form was applied to the participants to determine their perceptions about Graphic Design concept and the personal information. The metaphors was revealed with the sentences such as "Graphic design is like

. Because ................".

\subsection{Analysis of Data}

In the analysis of the data obtained from the research, content analysis was used from qualitative research methods. Content analysis can be defined as a systematic, repeatable technique in which some of the words within a text are summarized with smaller content categories with encodings made according to certain rules. It is a technique in which an objective and systematic recognition of certain features of a message is made. Content analysis is used to determine the existence of certain words or concepts in a cluster of text or texts (Büyüköztürk, Çakmak, Akgün, Karadeniz \& Demirel, 2011: 269). The data collected for this purpose should be conceptualized first, then rationally organized according to the emerging concepts and accordingly detected the themes explaining the data (Yıldırım \& Şimşek, 2011: 227).

The metaphors and responses obtained from the students about the questions of graphic design were analyzed in five stages. These are coding of the data, establishing the categories, arranging the data according to the codes and 
categories, providing the validity and reliability and interpretation of the data. At stage of data coding phase, metaphors produced by students were listed in alphabetical order and a list was created. While preparing the list, it is exhaustively examine whether the specific metaphor is clearly defined in the question form, and the documents belonging to the candidates who do not fill in the statement starts with "because" or any part of form. Then a list of sample metaphors was created to validate the data analysis process and use it as a resource for collecting metaphors under a certain category. The long- expressions used by the students were examined and their important aspects were taken into consideration. Encodings were used to indicate which metaphor images belong to the student (participants, P). At stage 2 ; during the creation of the categories, metaphors produced by the students were examined in terms of their common characteristics and analyzed for their relationship. At stage 3; the data were organized according to the codes and categories, and after the coding was done in detail, the categories which could bring together the codes related with each other were determined. At stage 4; after validity and reliability was done, expert opinions helped to confirm whether the metaphors presented under the eight conceptual categories developed in the study represent the conceptual categories to which they belong. For this purpose, two faculty members working at the same university were employed. At Stage 5; metaphor categories are tabulated and interpreted with information about frequency of using these metaphors and categories according to gender and grade. As a result, the data were interpreted according to these findings.

\section{Findings}

\subsection{Metaphors and Its Categories}

According to the results of content analysis, a total of 96 metaphors were produced for the concept of graphic design. Metaphors produced by the students participating in the study are arranged in alphabetical order and given in table 2 . According to the frequency results, the most repeated 11 metaphors and their frequencies are Dreaming (7), Universe (6), Freedom (6), Mathematics (4), Path (4), Love (3), Brain (3), All areas of Life (3), Musical (3), Life (3) and Entertainment (3). As shown in Table 2, 26 of the metaphors are represented by more than one student. The remaining 70 metaphors are represented by one student. In some cases, some students create more than one metophor for the concept of graphic design. Therefore, total frequency of metaphors is 145 .

Table 2. Metaphors of Graphic Design Department students about "Graphic Design" concept

\begin{tabular}{|c|c|c|}
\hline Metapfors & Frequency & Percentage \\
\hline Dreaming & 7 & 4,8 \\
\hline Freedom & 6 & 4,2 \\
\hline Universe & 6 & 4,2 \\
\hline Mathematics & 4 & 2,8 \\
\hline Path & 4 & 2,8 \\
\hline All Areas of Life & 3 & 2,1 \\
\hline Brain & 3 & 2,1 \\
\hline Entertainment & 3 & 2,1 \\
\hline Life & 3 & 2,1 \\
\hline Love & 3 & 2,1 \\
\hline Musical & 3 & 2,1 \\
\hline $\begin{array}{l}\text { A Different World, Baby, Child, Factory, Flower, Geometry, Idea-Thoughts, Innovation } \\
\text { - Original Thought, Life itself, Mind, Nature, Space Vacuum, Story, Subconscious, } \\
\text { Therapy (15 Metaphors) }\end{array}$ & 2 & 1,4 \\
\hline $\begin{array}{l}\text { A Part of Nature, A Very Good Job, Advertiser, Animation, Arrow, Art, Art Creation } \\
\text { with the Spirit, Beginning of Birth, Brainstorming, Cartoon, Chain, Clew, Computer, } \\
\text { Consultant, Creativity, Design, Detective, Dream, Dream World, Everything that } \\
\text { Advertised, Everything the Eye Sees, Eyesight, Facilitation, Field of Art, Football, Gift } \\
\text { Package, Grafon Paper, Hobby, Human, Impulse, Labyrinth, Landscape, Laugh, Law of } \\
\text { Nature, Line, Machine, Magician, Marketing, Material, Messaging with Pigeon, } \\
\text { Mirror, Mixer, Myself, Painting, Parents, Perspective, Physics, Poetry, Quantum } \\
\text { Mechanics, Rainbow, Ratio and Proportion, Research, Sea of Thought, Seed, Sky, } \\
\text { Society, Spirit, Story Narrator, Sun, Surprise Egg, the Director of Nature, the Way to } \\
\text { Express Myself, The World that dreams are realized, Thoughts in us, Top Level, } \\
\text { Transfer the Dream, Tree, Truth of Life, Visual Communication, Water (70 Metaphors) }\end{array}$ & 1 & 0,7 \\
\hline Total & 145 & 100,0 \\
\hline
\end{tabular}

3.2 Conceptual Categories of the Metaphors Based on Common Characteristics

The metaphors created for the concept of graphic design were categorized according to their common characteristics and similarities. These categories and metaphors in these categories are shown in Table 3. As shown in the table, 8 categories were obtained. These categories are effort or labor dependent structure, unlimited structure, useful structure 
that facilitates life, multi-dimensional structure, target-oriented structure, changeable structure, holistic structure, uniform structure. The students created metaphors which they perceived as "unlimited structure"(18.7\%) and "target-oriented structure" (18\%) to explain the concept of graphic design.

Table 3. The categories of metaphors created by graphic designer candidates for the concept of Graphic Design

\begin{tabular}{|c|c|c|c|c|c|}
\hline : & Metaphors & 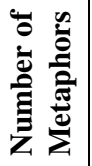 & 莺 & : & Example of Statements for Metaphors \\
\hline 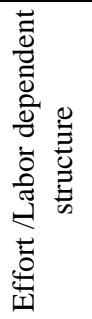 & $\begin{array}{l}\text { Idea-thought (2), Dreaming (1), The World } \\
\text { that dreams are realized (1), Path (1), } \\
\text { Football (1), Labyrinth (1), Grafon paper } \\
\text { (1), Research (1), Brain (1), Law of Nature } \\
\text { (1), Seed (1), Flower (1), Physics (1), Gift } \\
\text { Package (1) }\end{array}$ & 14 & 15 & 10.8 & $\begin{array}{l}\text { P-33: Graphic design is like a labyrinth } \\
\text { because it's hard to learn and grasp, but } \\
\text { after learning it's very nice and very good. } \\
\text { P-109: I think graphic design is a brain, } \\
\text { because it requires much thinking. }\end{array}$ \\
\hline 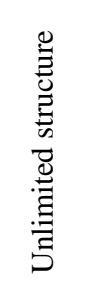 & $\begin{array}{l}\text { The truth of life (1), Brainstorming (1), A } \\
\text { Part of nature (1), Life (2), Spirit (1), } \\
\text { Universe (5), Sky (1), Everything the eye } \\
\text { sees (1), Mind (1), Line (1), Dreaming (1), } \\
\text { Freedom (2), Detective (1), Art (1), Brain } \\
\text { (1), Path (1), Space Vacuum (2), Life itself } \\
\text { (1), Painting (1) }\end{array}$ & 19 & 26 & 18.7 & $\begin{array}{l}\text { P-1: Graphic design is like the universe } \\
\text { because there is an endless way of doing } \\
\text { a design just like the universe. } \\
\text { P-3: Graphic design is like the sky } \\
\text { because it is infinite and open to design } \\
\text { like clouds. }\end{array}$ \\
\hline 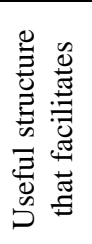 & $\begin{array}{l}\text { Machine (1), Sun (1), Quantum mechanics } \\
\text { (1), Laugh (1), Water (1), Messaging with } \\
\text { Pigeon (1), Dreaming (1), Freedom (2), } \\
\text { Idea-thought (1) }\end{array}$ & 9 & 10 & 7.2 & $\begin{array}{l}\text { P-15:Graphic design is like the sun } \\
\text { because it gives the world light and color. } \\
\text { P-32: Graphic design is like the water, } \\
\text { because we need a graphic design as we } \\
\text { need water. }\end{array}$ \\
\hline 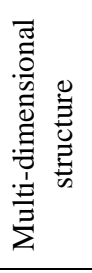 & $\begin{array}{l}\text { Rainbow (1), Society (1), Design (1), Clew } \\
\text { (1), Dreaming (1), Freedom (1), Musical } \\
\text { (1), Geometry (1), Mathematics (1), Life } \\
\text { (1), Love (3), Top Level (1), Field of Art } \\
\text { (1), Entertainment (1), Landscape (1), } \\
\text { Myself (1), Mirror (1), Research (1), A } \\
\text { Very Good Job (1) }\end{array}$ & 19 & 21 & 15.1 & $\begin{array}{l}\text { P-10: Graphic design is like the rainbow } \\
\text { because it is colorful and varieties } \\
\text { P-24: Graphic design is like the society, } \\
\text { because it contains all creativity content. }\end{array}$ \\
\hline 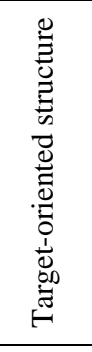 & $\begin{array}{l}\text { Story (2), Impulse (1), All areas of life (2), } \\
\text { Consultant (1), Parents (1), Visual } \\
\text { communication (1), A different world (1), } \\
\text { Dreaming (2), Dream (1), Subconscious } \\
\text { (1), Therapy (2), Entertainment (2), The } \\
\text { Director of Nature (1), Nature (1), } \\
\text { Facilitation (1), Art creation with the spirit } \\
\text { (1), Eyesight (1), The way to express } \\
\text { myself (1), Arrow (1), Flower (1) }\end{array}$ & 20 & 25 & 18.0 & $\begin{array}{l}\text { P-28: Graphic design is like the all areas } \\
\text { of life, because it is in every aspect of life } \\
\text { and enables us to see. } \\
\text { P-134: Graphic design is like the eyesight } \\
\text { because it allows us to see and understand } \\
\text { everything. }\end{array}$ \\
\hline 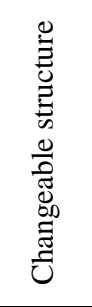 & $\begin{array}{l}\text { Universe (1), Computer (1), Baby (2), } \\
\text { Magician (1), Beginning of birth (1), } \\
\text { Material (1), Dreaming (1), Thoughts in us } \\
\text { (1), Innovation- original thought (1), Sea of } \\
\text { Thought (1), Musical (2), Subconscious (1), } \\
\text { Perspective (1), Factory (2), Space vacuum } \\
\text { (1), Path (2), Surprise egg (1), Tree (1), A } \\
\text { Different World (1) }\end{array}$ & 19 & 23 & 16.5 & $\begin{array}{l}\text { P-7: Graphic design is like a fantastic } \\
\text { universe because it can transfer things a } \\
\text { quite differently with graphics. Another } \\
\text { world of communication. } \\
\text { P-115: Graphic design is like a path, } \\
\text { because I can differentiate the paths I've } \\
\text { gone. }\end{array}$ \\
\hline
\end{tabular}




\begin{tabular}{|c|c|c|c|c|c|}
\hline 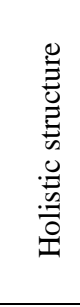 & $\begin{array}{l}\text { Cartoon (1), Human (1), Life itself (1), } \\
\text { Freedom (1), Child (1) Mixer (1), Story } \\
\text { narrator (1), Design (1) }\end{array}$ & 8 & 8 & 5.8 & $\begin{array}{l}\text { P-13: Graphic design is like a cartoon } \\
\text { because I know that while watching } \\
\text { cartoons, they are all composed of } \\
\text { individual lines and that they are related } \\
\text { to graphics. } \\
\text { P-85: Graphic design is like a child } \\
\text { because they are the seeds of the the } \\
\text { nation and the future of society. }\end{array}$ \\
\hline 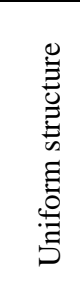 & $\begin{array}{l}\text { Mathematics (3), Poetry (1), Marketing (1), } \\
\text { Geometry (1), Nature (1), Mind (1), } \\
\text { Ratio-Proportion (1), Advertiser (1), Child } \\
\text { (1) }\end{array}$ & 9 & 11 & 7.9 & $\begin{array}{l}\text { P-22: Graphic design is like the } \\
\text { mathematics because it depends on } \\
\text { systematic rules in itself as in the } \\
\text { graphics. } \\
\text { P-98: Graphic design is like the geometry } \\
\text { because it contains geometric terms. }\end{array}$ \\
\hline Total & & 117 & 139 & 100 & \\
\hline
\end{tabular}

\subsection{Differentiation of the concept of Graphic Design based on Gender and Grades}

It was evaluated by the metaphor formed by the students about the graphic design concept. Frequency and total percentage (\%) of metaphors according to gender and grades based on categories are given in Table 4.

Most of the female students perceive the concept of graphic design as an unlimited structure (19.8\%) and a changeable structure (18.6\%). A few of them perceive the concept of graphic design as a holistic structure $(5.8 \%)$ and a uniform structure (5.8\%). Most of the male students perceive the concept of graphic design as a target-oriented structure (22.6\%) and an unlimited structure (17\%). A few of them perceive the concept of graphic design as a useful structure that facilitates $(5.7 \%)$ and a holistic structure (5.7\%). The common perception of both male and female students participating in the study is the least expression of a holistic structure.

In the 1st Grade, the concept of Graphic Design was expressed as a target-oriented structure (19.6\%) and unlimited structure (25.5\%) mostly. A useful structure that facilitates (5.9\%) was least expressed. In the 2nd grade, target-oriented structure (25.8\%) was preferred mostly and a uniform structure (3.2\%) leastly. As seen in Table 4, among the 3rd grade students, unlimited structure (24.1\%) was expressed mostly and a holistic structure (3.4\%) and a useful structure that facilitates $(3.5 \%)$ have the same percentage. In 3rd Grade and 1st Grade, there is a common perception that they expressed the concept of graphic design as an unlimited structure and a useful structure that facilitates. In the 4th grade, the concept of Graphic Design was expressed as a effort-labor dependent structure $(21,4 \%)$ and changeable structure (21.4\%) and the holistic structure (3.5\%) was least expressed. In general, unlimited structure are expressed by $18.3 \%$ and a holistic structure is $5.6 \%$ based on the answers from students.

Table 4. Categorical Distribution of metaphors about graphic design concept according to gender and grades

a. Effort / Labor Dependent Structure

\begin{tabular}{|c|c|c|c|c|c|c|c|}
\hline \multirow{2}{*}{ Metaphors } & \multicolumn{2}{|c|}{ Gender } & \multicolumn{4}{|c|}{ Grades } & \multirow{2}{*}{$\begin{array}{c}\text { Total } \\
139\end{array}$} \\
\hline & $\begin{array}{c}\text { Female } \\
(86)\end{array}$ & $\begin{array}{l}\text { Male } \\
(53)\end{array}$ & $\begin{array}{c}\text { 1st Grade } \\
\text { (51) }\end{array}$ & $\begin{array}{c}\text { 2nd Grade } \\
\text { (31) }\end{array}$ & $\begin{array}{l}\text { 3rd Grade } \\
\text { (29) }\end{array}$ & $\begin{array}{l}\text { 4th Grade } \\
\text { (28) }\end{array}$ & \\
\hline Idea Thoughts & 2 & 0 & 0 & 0 & 1 & 1 & 2 \\
\hline Dream & 1 & 0 & 0 & 1 & 0 & 0 & 1 \\
\hline The World that dreams are realized & 0 & 1 & 1 & 0 & 0 & 0 & 1 \\
\hline Path & 1 & 0 & 0 & 0 & 0 & 1 & 1 \\
\hline Football & 0 & 1 & 1 & 0 & 0 & 0 & 1 \\
\hline Labyrinth & 1 & 0 & 0 & 0 & 0 & 1 & 1 \\
\hline Grafon paper & 0 & 1 & 1 & 0 & 0 & 0 & 1 \\
\hline Research & 1 & 0 & 0 & 0 & 1 & 0 & 1 \\
\hline Brain & 1 & 0 & 0 & 0 & 0 & 1 & 1 \\
\hline Law of Nature & 0 & 1 & 0 & 0 & 0 & 1 & 1 \\
\hline Seed & 0 & 1 & 0 & 1 & 0 & 0 & 1 \\
\hline Flower & 1 & 0 & 0 & 1 & 0 & 0 & 1 \\
\hline Physics & 1 & 0 & 1 & 0 & 0 & 0 & 1 \\
\hline Gift Package & 0 & 1 & 0 & 0 & 0 & 1 & 1 \\
\hline Total & 9 & 6 & 4 & 3 & 2 & 6 & 15 \\
\hline Percentage & $10.5 \%$ & $11.3 \%$ & $7.8 \%$ & $9.7 \%$ & $6.9 \%$ & $21.4 \%$ & $10.6 \%$ \\
\hline
\end{tabular}


b. Unlimited Structure

\begin{tabular}{l|c|c|c|c|c|c|c}
\hline \multirow{2}{*}{ Metaphors } & \multicolumn{2}{|c|}{ Gender } & \multicolumn{3}{c}{ Grades } & Total \\
\cline { 2 - 8 } & $\begin{array}{c}\text { Female } \\
(86)\end{array}$ & $\begin{array}{c}\text { Male } \\
(53)\end{array}$ & $\begin{array}{c}1 \text { st Grade } \\
(51)\end{array}$ & $\begin{array}{c}2 \text { nd Grade } \\
(31)\end{array}$ & $\begin{array}{c}\text { 3rd Grade } \\
(29)\end{array}$ & $\begin{array}{c}4 \text { th Grade } \\
(28)\end{array}$ & 139 \\
\hline Truth of life & 1 & 0 & 1 & 0 & 0 & 0 & 1 \\
\hline Brainstorming & 1 & 0 & 0 & 0 & 0 & 1 & 1 \\
\hline Part of nature & 0 & 1 & 0 & 0 & 1 & 0 & 1 \\
\hline Life & 2 & 0 & 1 & 0 & 1 & 0 & 2 \\
\hline Spirit & 0 & 1 & 1 & 0 & 0 & 0 & 1 \\
\hline Universe & 2 & 3 & 4 & 0 & 1 & 0 & 5 \\
\hline Sky & 1 & 0 & 1 & 0 & 0 & 0 & 1 \\
\hline Everything the Eye sees & 1 & 0 & 1 & 0 & 0 & 0 & 1 \\
\hline Mind & 1 & 0 & 1 & 0 & 0 & 0 & 1 \\
\hline Painting & 0 & 1 & 1 & 0 & 0 & 0 & 1 \\
\hline Line & 1 & 0 & 1 & 0 & 0 & 0 & 1 \\
\hline Dreaming & 1 & 0 & 0 & 0 & 0 & 1 & 1 \\
\hline Freedom & 2 & 0 & 0 & 0 & 2 & 0 & 2 \\
\hline Detective & 0 & 1 & 0 & 1 & 0 & 0 & 1 \\
\hline Art & 1 & 0 & 1 & 0 & 0 & 0 & 1 \\
\hline Brain & 0 & 1 & 0 & 0 & 1 & 0 & 1 \\
\hline Path & 1 & 0 & 0 & 1 & 0 & 0 & 1 \\
\hline Space Vacuum & 1 & 1 & 0 & 1 & 1 & 0 & 2 \\
\hline Life itself & 1 & 0 & 0 & 0 & 0 & 1 & 1 \\
\hline & $\mathbf{1 7}$ & $\mathbf{9}$ & $\mathbf{1 3}$ & $\mathbf{3}$ & $\mathbf{7}$ & $\mathbf{3}$ & $\mathbf{2 6}$ \\
\hline & & & & $\mathbf{2 4 . 1 \%}$ & $\mathbf{1 0 . 7 \%}$ & $\mathbf{1 8 . 3 \%}$ \\
\hline
\end{tabular}

c. Useful structure that facilitates

\begin{tabular}{|c|c|c|c|c|c|c|c|}
\hline \multirow[t]{2}{*}{ Metaphors } & \multicolumn{2}{|c|}{ Gender } & \multicolumn{4}{|c|}{ Grades } & \multirow{2}{*}{$\begin{array}{l}\text { Total } \\
139\end{array}$} \\
\hline & $\begin{array}{c}\text { Female } \\
(86)\end{array}$ & $\begin{array}{l}\text { Male } \\
(53)\end{array}$ & $\begin{array}{l}\text { 1st Grade } \\
\text { (51) }\end{array}$ & $\begin{array}{l}\text { 2nd Grade } \\
\text { (31) }\end{array}$ & $\begin{array}{l}\text { 3rd Grade } \\
\text { (29) }\end{array}$ & $\begin{array}{l}\text { 4th Grade } \\
\text { (28) }\end{array}$ & \\
\hline Machine & 1 & 0 & 1 & 0 & 0 & 0 & 1 \\
\hline Sun & 0 & 1 & 0 & 1 & 0 & 0 & 1 \\
\hline Quantum Mechanics & 0 & 1 & 0 & 0 & 0 & 1 & 1 \\
\hline Laugh & 1 & 0 & 0 & 0 & 0 & 1 & 1 \\
\hline Water & 1 & 0 & 1 & 0 & 0 & 0 & 1 \\
\hline Messaging with Pigeons & 1 & 0 & 0 & 0 & 0 & 1 & 1 \\
\hline Dreaming & 0 & 1 & 0 & 0 & 0 & 1 & 1 \\
\hline Freedom & 2 & 0 & 1 & 0 & 1 & 0 & 2 \\
\hline Idea-thoughts & 1 & 0 & 0 & 1 & 0 & 0 & 1 \\
\hline Total & 7 & 3 & 3 & 2 & 1 & 4 & 10 \\
\hline Percentage & $8.1 \%$ & $5.7 \%$ & $5.7 \%$ & $6.5 \%$ & $3.5 \%$ & $14.3 \%$ & $7.0 \%$ \\
\hline
\end{tabular}


d. Multi-dimensional structure

\begin{tabular}{|c|c|c|c|c|c|c|c|}
\hline \multirow[t]{2}{*}{ Metaphors } & \multicolumn{2}{|c|}{ Gender } & \multicolumn{4}{|c|}{ Grades } & \multirow{2}{*}{$\begin{array}{c}\text { Total } \\
139\end{array}$} \\
\hline & $\begin{array}{c}\text { Female } \\
(86)\end{array}$ & $\begin{array}{c}\text { Male } \\
(53)\end{array}$ & $\begin{array}{l}\text { 1st Grade } \\
\text { (51) }\end{array}$ & $\begin{array}{c}\text { 2nd Grade } \\
\text { (31) }\end{array}$ & $\begin{array}{l}\text { 3rd Grade } \\
\text { (29) }\end{array}$ & $\begin{array}{l}\text { 4th Grade } \\
\text { (28) }\end{array}$ & \\
\hline Rainbow & 1 & 0 & 1 & 0 & 0 & 0 & 1 \\
\hline Society & 0 & 1 & 1 & 0 & 0 & 0 & 1 \\
\hline Design & 1 & 0 & 0 & 1 & 0 & 0 & 1 \\
\hline Ball & 1 & 0 & 1 & 0 & 0 & 0 & 1 \\
\hline Dreaming & 1 & 0 & 0 & 1 & 0 & 0 & 1 \\
\hline Freedom & 1 & 0 & 1 & 0 & 0 & 0 & 1 \\
\hline Musical & 1 & 0 & 0 & 0 & 1 & 0 & 1 \\
\hline Geometry & 0 & 1 & 0 & 0 & 0 & 1 & 1 \\
\hline Mathematics & 0 & 1 & 0 & 0 & 1 & 0 & 1 \\
\hline Life & 1 & 0 & 0 & 0 & 0 & 1 & 1 \\
\hline Love & 2 & 1 & 1 & 0 & 1 & 1 & 3 \\
\hline Top level & 1 & 0 & 0 & 1 & 0 & 0 & 1 \\
\hline Field of Art & 0 & 1 & 0 & 1 & 0 & 0 & 1 \\
\hline A very Good Job & 1 & 0 & 1 & 0 & 0 & 0 & 1 \\
\hline Entertainment & 1 & 0 & 1 & 0 & 0 & 0 & 1 \\
\hline Landscape & 1 & 0 & 0 & 1 & 0 & 0 & 1 \\
\hline Myself & 0 & 1 & 0 & 1 & 0 & 0 & 1 \\
\hline Mirror & 0 & 1 & 1 & 0 & 0 & 0 & 1 \\
\hline Research & 1 & 0 & 0 & 0 & 1 & 0 & 1 \\
\hline Total & 14 & 7 & 8 & 6 & 4 & 3 & 21 \\
\hline Percentage & $16.3 \%$ & $13.2 \%$ & $15.7 \%$ & $19.4 \%$ & $13.8 \%$ & $10.7 \%$ & $14.8 \%$ \\
\hline
\end{tabular}

e. Target-oriented structure

\begin{tabular}{l|c|c|c|c|c|c|c}
\hline \multirow{2}{*}{ Metaphors } & \multicolumn{2}{|c|}{ Gender } & \multicolumn{2}{c}{ Grades } & Total \\
\cline { 2 - 8 } & $\begin{array}{c}\text { Female } \\
(86)\end{array}$ & $\begin{array}{c}\text { Male } \\
(53)\end{array}$ & $\begin{array}{c}1 \text { st Grade } \\
(51)\end{array}$ & $\begin{array}{c}\text { 2nd Grade } \\
(31)\end{array}$ & $\begin{array}{c}\text { 3rd Grade } \\
(29)\end{array}$ & $\begin{array}{c}4 \text { th Grade } \\
(28)\end{array}$ & 139 \\
\hline Story & 1 & 1 & 2 & 0 & 0 & 0 & 2 \\
\hline Impulse & 1 & 0 & 0 & 0 & 1 & 0 & 1 \\
\hline All areas of Life & 0 & 2 & 1 & 0 & 1 & 0 & 2 \\
\hline Consultant & 0 & 1 & 1 & 0 & 0 & 0 & 1 \\
\hline Parent & 0 & 1 & 0 & 1 & 0 & 0 & 1 \\
\hline Visual communication & 0 & 1 & 0 & 1 & 0 & 0 & 1 \\
\hline A Different world & 0 & 1 & 0 & 0 & 1 & 0 & 1 \\
\hline Arrow & 0 & 1 & 0 & 1 & 0 & 0 & 1 \\
\hline Dreaming & 2 & 0 & 1 & 0 & 0 & 1 & 2 \\
\hline Dream & 1 & 0 & 0 & 1 & 0 & 0 & 1 \\
\hline Subconscious & 1 & 0 & 0 & 1 & 0 & 0 & 1 \\
\hline Therapy & 1 & 1 & 0 & 0 & 1 & 1 & 2 \\
\hline Entertainment & 1 & 1 & 1 & 1 & 0 & 0 & 2 \\
\hline The Director of Nature & 1 & 0 & 1 & 0 & 0 & 0 & 1 \\
\hline Flower & 0 & 1 & 0 & 0 & 1 & 0 & 1 \\
\hline Nature & 1 & 0 & 1 & 0 & 0 & 0 & 1 \\
\hline Facilitation & 0 & 1 & 1 & 0 & 0 & 0 & 1 \\
\hline Art Creation with the spirit & 1 & 0 & 1 & 0 & 0 & 0 & 1 \\
\hline Eyesight & 1 & 0 & 0 & 1 & 0 & 0 & 1 \\
\hline The way to express yourself & 1 & 0 & 0 & 1 & 0 & 0 & 1 \\
\hline & $\mathbf{1 3}$ & $\mathbf{1 2}$ & $\mathbf{1 0}$ & $\mathbf{8}$ & $\mathbf{5}$ & $\mathbf{2}$ & $\mathbf{2 5}$ \\
\hline & $\mathbf{1 5 . 1 \%}$ & $\mathbf{2 2 . 6 \%}$ & $\mathbf{1 9 . 6 \%}$ & $\mathbf{2 5 . 8 \%}$ & $\mathbf{1 7 . 2 \%}$ & $\mathbf{7 . 1 \%}$ & $\mathbf{1 7 . 6 \%}$ \\
\hline
\end{tabular}


f. Changeable structure

\begin{tabular}{l|c|c|c|c|c|c|c}
\hline \multirow{2}{*}{ Metaphors } & \multicolumn{2}{|c|}{ Gender } & \multicolumn{3}{c}{ Grades } & Total \\
\cline { 2 - 8 } & $\begin{array}{c}\text { Female } \\
(86)\end{array}$ & $\begin{array}{c}\text { Male } \\
(53)\end{array}$ & $\begin{array}{c}1 \text { st Grade } \\
(51)\end{array}$ & $\begin{array}{c}\text { 2nd Grade } \\
(31)\end{array}$ & $\begin{array}{c}\text { 3rd Grade } \\
(29)\end{array}$ & $\begin{array}{c}\text { 4th Grade } \\
(28)\end{array}$ & 139 \\
\hline Universe & 1 & 0 & 0 & 1 & 0 & 0 & 1 \\
\hline Computer & 1 & 0 & 0 & 0 & 1 & 0 & 1 \\
\hline Baby & 2 & 0 & 1 & 0 & 0 & 1 & 2 \\
\hline Magician & 1 & 0 & 0 & 0 & 1 & 0 & 1 \\
\hline Beginning of birth & 1 & 0 & 1 & 0 & 0 & 0 & 1 \\
\hline Material & 0 & 1 & 0 & 0 & 0 & 1 & 1 \\
\hline Dreaming & 1 & 0 & 0 & 1 & 0 & 0 & 1 \\
\hline Thoughts in us & 1 & 0 & 1 & 0 & 0 & 0 & 1 \\
\hline Innovation-original thinking & 1 & 0 & 0 & 1 & 0 & 0 & 1 \\
\hline Sea of Thought & 1 & 0 & 0 & 0 & 0 & 1 & 1 \\
\hline Musical & 1 & 1 & 0 & 0 & 1 & 1 & 2 \\
\hline Subconscious & 1 & 0 & 0 & 1 & 0 & 0 & 1 \\
\hline Perspective & 0 & 1 & 1 & 0 & 0 & 0 & 1 \\
\hline Factory & 2 & 0 & 0 & 1 & 0 & 1 & 2 \\
\hline Space Vacuum & 0 & 1 & 0 & 0 & 1 & 0 & 1 \\
\hline Path & 1 & 1 & 1 & 0 & 1 & 0 & 2 \\
\hline Surprise egg & 0 & 1 & 0 & 0 & 0 & 1 & 1 \\
\hline Tree & 0 & 1 & 0 & 1 & 0 & 0 & 1 \\
\hline A Different world & 1 & 0 & 0 & 0 & 1 & 0 & 1 \\
\hline & $\mathbf{1 6}$ & $\mathbf{7}$ & $\mathbf{5}$ & $\mathbf{6}$ & $\mathbf{6}$ & $\mathbf{6}$ & $\mathbf{2 3}$ \\
\hline & & & & $\mathbf{2 0 . 7 \%}$ & $\mathbf{2 1 . 4 \%}$ & $\mathbf{1 6 . 2 \%}$ \\
\hline
\end{tabular}

g. Holistic structure

\begin{tabular}{|c|c|c|c|c|c|c|c|}
\hline \multirow[t]{2}{*}{ Metaphors } & \multicolumn{2}{|c|}{ Gender } & \multicolumn{4}{|c|}{ Grades } & \multirow{2}{*}{$\begin{array}{c}\text { Total } \\
139\end{array}$} \\
\hline & $\begin{array}{c}\text { Female } \\
(86)\end{array}$ & $\begin{array}{l}\text { Male } \\
(53)\end{array}$ & $\begin{array}{l}\text { 1st Grade } \\
\text { (51) }\end{array}$ & $\begin{array}{c}\text { 2nd Grade } \\
\text { (31) }\end{array}$ & $\begin{array}{c}\text { 3rd Grade } \\
\text { (29) }\end{array}$ & $\begin{array}{c}\text { 4th Grade } \\
\text { (28) }\end{array}$ & \\
\hline Cartoon & 1 & 0 & 1 & 0 & 0 & 0 & 1 \\
\hline Human & 0 & 1 & 1 & 0 & 0 & 0 & 1 \\
\hline Design & 1 & 0 & 0 & 1 & 0 & 0 & 1 \\
\hline Story Narrator & 1 & 0 & 1 & 0 & 0 & 0 & 1 \\
\hline Life itself & 0 & 1 & 0 & 0 & 0 & 1 & 1 \\
\hline Freedom & 1 & 0 & 0 & 1 & 0 & 0 & 1 \\
\hline Child & 0 & 1 & 0 & 0 & 1 & 0 & 1 \\
\hline Mixer & 1 & 0 & 1 & 0 & 0 & 0 & 1 \\
\hline Total & 5 & 3 & 4 & 2 & 1 & 1 & 8 \\
\hline Percentage & $5.8 \%$ & $5.7 \%$ & $7.8 \%$ & $6.5 \%$ & $3.4 \%$ & $3.6 \%$ & $5.6 \%$ \\
\hline
\end{tabular}

h. Uniform structure

\begin{tabular}{|c|c|c|c|c|c|c|c|}
\hline \multirow[t]{2}{*}{ Metaphors } & \multicolumn{2}{|c|}{ Gender } & \multicolumn{4}{|c|}{ Grades } & \multirow{2}{*}{$\begin{array}{l}\text { Total } \\
139\end{array}$} \\
\hline & $\begin{array}{c}\text { Female } \\
(86)\end{array}$ & $\begin{array}{c}\text { Male } \\
(53)\end{array}$ & $\begin{array}{l}\text { 1st Grade } \\
\text { (51) }\end{array}$ & $\begin{array}{l}\text { 2nd Grade } \\
\text { (31) }\end{array}$ & $\begin{array}{l}\text { 3rd Grade } \\
\text { (29) }\end{array}$ & $\begin{array}{l}\text { 4th Grade } \\
\text { (28) }\end{array}$ & \\
\hline Mathematics & 2 & 1 & 2 & 0 & 1 & 0 & 3 \\
\hline Mind & 0 & 1 & 1 & 0 & 0 & 0 & 1 \\
\hline Ratio and proportion & 0 & 1 & 0 & 0 & 0 & 1 & 1 \\
\hline Poetry & 1 & 0 & 0 & 1 & 0 & 0 & 1 \\
\hline Marketing & 0 & 1 & 0 & 0 & 0 & 1 & 1 \\
\hline Child & 0 & 1 & 0 & 0 & 1 & 0 & 1 \\
\hline Geometry & 0 & 1 & 0 & 0 & 1 & 0 & 1 \\
\hline Nature & 1 & 0 & 1 & 0 & 0 & 0 & 1 \\
\hline Advertiser & 1 & 0 & 0 & 0 & 0 & 1 & 1 \\
\hline Total & 5 & 6 & 4 & 1 & 3 & 3 & 11 \\
\hline Percentage & $5.8 \%$ & $11.3 \%$ & $7.8 \%$ & $3.2 \%$ & $10.3 \%$ & $10.7 \%$ & $7.7 \%$ \\
\hline
\end{tabular}




\section{Conclusion and Suggestions}

The perceptions of students who received Graphic Design education were determined by metaphors according to gender and grades. The majority of the students participated in the study produced metaphors with positive and abstract. First of all, metaphor is not the phenomenon of itself, it is only a symbol. If this was the case itself, the metaphor would not be needed. Therefore, the metaphor is different from the fact that it represents. Although it presents a very strong perspective on this phenomenon, it is often less than that. Many metaphors must be employed to compensate for this situation. (Yob, 2003: 133-134; Saban, Koçbeker \& Saban, 2006: 504).

In the study, many metaphors related to the concept of graphic design have been produced but mostly consist of abstract concepts. There are studies show that art education increases students' abstract thinking abilities (Mutlu \& Kanat, 2017: 732). Students mostly have created positive thoughts about graphic design by using metaphors. In the literature, this kind of study has not been found related to the students who received graphic design education. Özgün, Gürkan and Kahraman (2018) revealed the perceptions of prospective teachers about the concepts of "science" and "scientists" through metaphors, and in this study, prospective teachers needed many metaphors.

According to the research findings, graphic design students generally perceived the concept of graphic design as an unlimited structure (18.3\%). Because, communication is the basis of graphic design that has contemporary and dynamic structure. As Becer (2015) stated, "the graphic designer has to present a contemporary knowledge using contemporary tools and materials in a modern sense of appreciation. Therefore, designer should closely follow current trends, artistic, philosophical, political, sociological issues and developing technology. In order to be successful in this field, designers have to keep its information up to date and maintain the innovation. This means lifelong learning. On the other hand, the graphic design, which takes its place in every area of life, is used in an unlimited practical area such as the signs used to prevent accidents in traffic, the table showing the amount of cholesterol in the food consumed and the movie trailers (Twemlow, 2011; Akt: Atalay \& Kanat, 2018).

According to the findings, it is seen that gender factor plays a decisive role in the graphic design concept of the students. In the study, female students perceive the concept of graphic design as an "unlimited structure" $(19.8 \%)$ whereas male students perceive the concept as a "target-oriented structure" (22.6\%) as seen in figure 1.

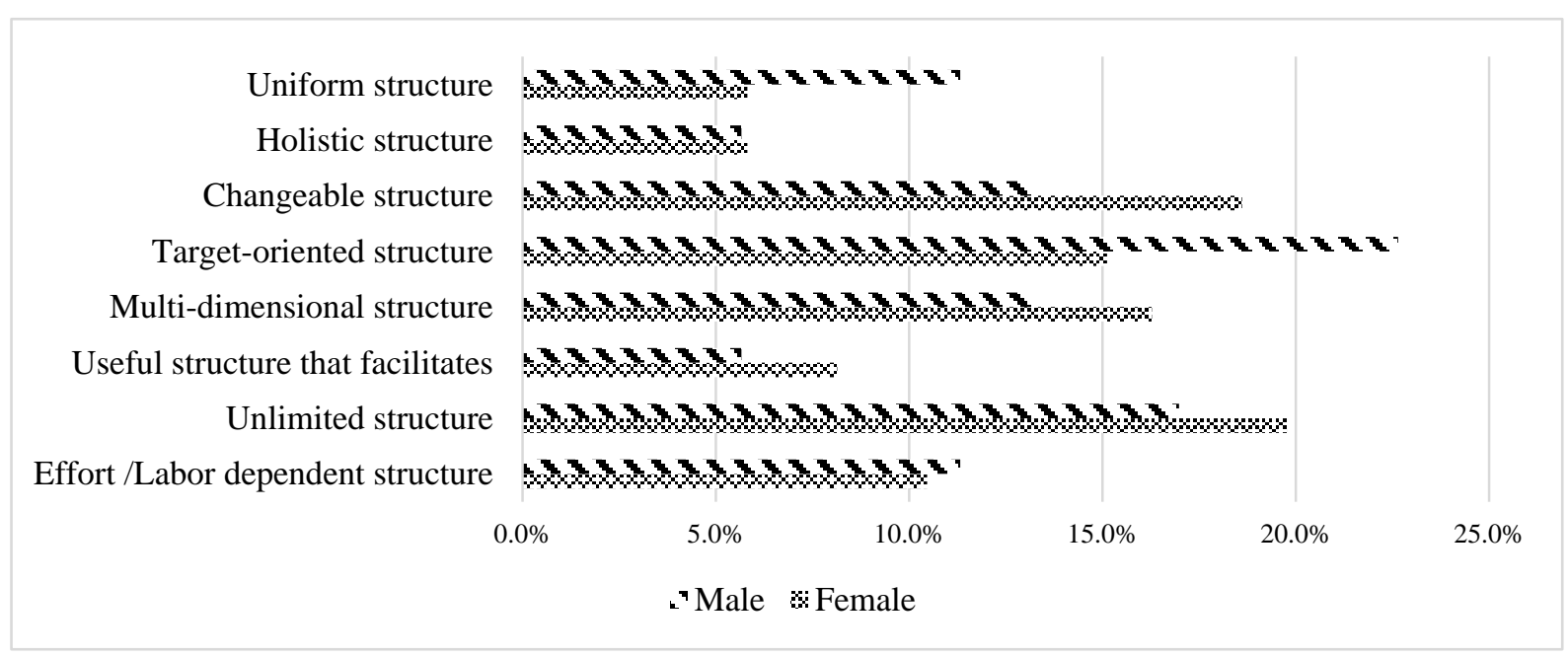

Figure 1. Gender Distribution of Categorie

There are studies showing that the gender factor as in the research findings affects the creation of metaphor when the literature is reviewed (Özgün et al., 2018; Yüceil, 2015; Akyıldız, 2017; Yıldız, 2014). However, there are studies that do not show parallelism with the findings (Kelleci, 2014; Pektaş \& Kıldan, 2009; Beyoğlu \& Ergin, 2018). 
The other finding obtained from the study is that the grades of the university students who take graphic design education is an effective factor on the perception of graphic design concept. In the literature, there are studies that support the findings on this aspect (Özgün et al. 2018; Akyıldız, 2017). Grade factor is effective in creating metaphors as seen in figure 2. Most created metaphors for the concept of graphic design are "unlimited structure" among most of 1st Grade and 3rd Grade students. The concept of graphic design is perceived as a "target-oriented structure" by 2nd Grade students and perceived as a "changeable structure" and a "labor-dependent structure" by 4th Grade students. It is important that Grade 4 students, who have more knowledge of the concept of graphic design than others in terms of professional field knowledge, perceive as the "effort/labor dependent structure" (21.4\%) and changeable structure (\%21.4).

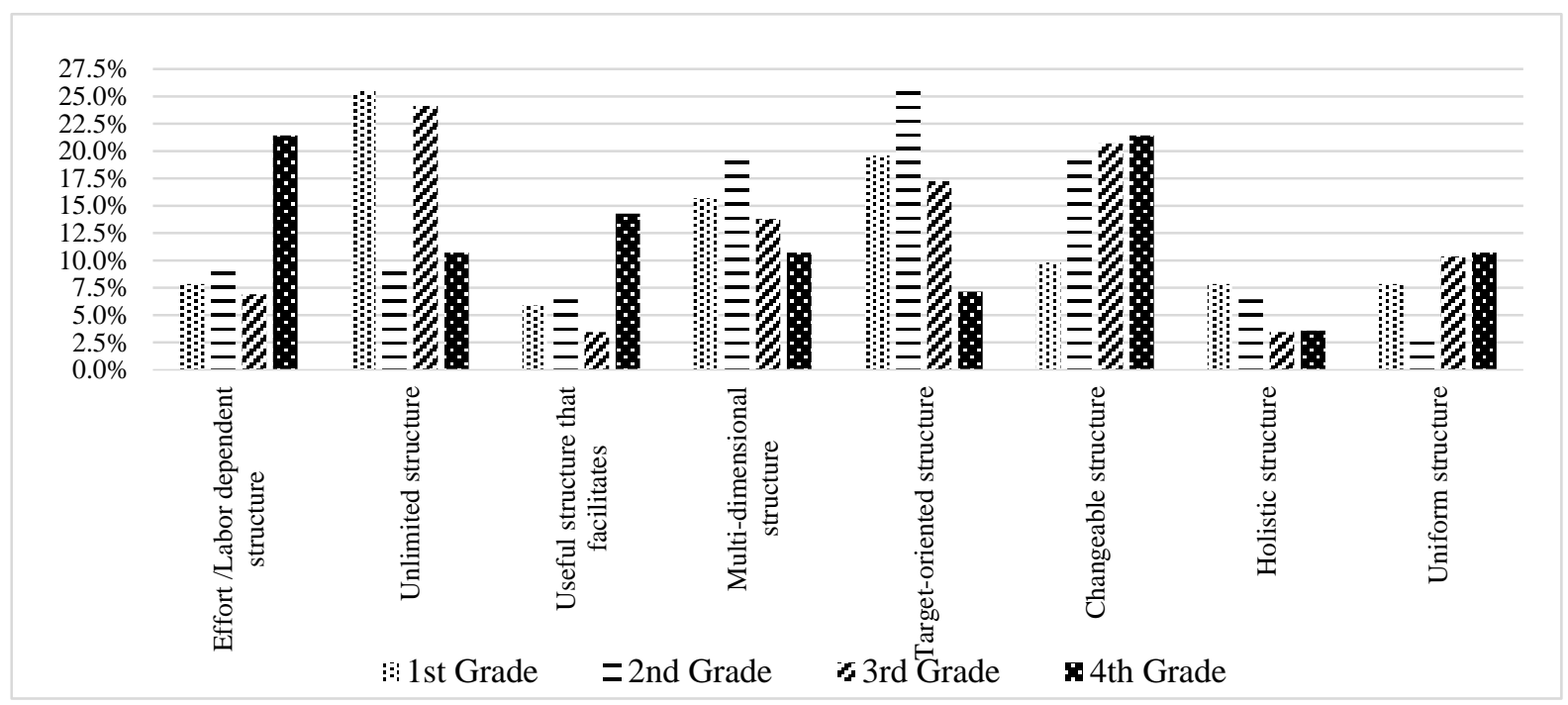

Figure 2. Grade Distribution of Categories

It is important to emphasize that the field of graphic design, which requires lifelong learning, is an area that requires labor and effort. Self-development, accurate understanding of the nature of the graphic design and being aware of this is positive results of the this research. The metaphors obtained in the study may be the source for the researchers who will work in this field.

\section{References}

Ağsakallı, M. S. (2014).The Effect of The Movement of Surrealism on Poster Designing and Practice Examples (Master Thesis). Atatürk University The Institute of Social Sciences, Erzurum.

Akyıldız, N. (2017). Investigation of High School Students' Metaphorical School Perceptions: Diyarbakır Example. (MBA Thesis), Çağ University The Institute of Social Sciences Psychology Department, Tarsus/Mersin.

Altıntaş, Z. (2005). Nature Forms As A 'Metafor' in Sculpture in the Period After 1960. (Master's Thesis) Marmara University, Institute of Fine Arts, Istanbul.

Arntson, A. (2012). Graphic Design Basics (6th Ed.). USA: Wadsworth, Cengage Learning

Atalay, M. C., \& Kanat, S. (2018). Exhibition Posters That Are Designed For Painters. Social Sciences Studies Journal, 4(20), 2894-2902.

Becer, E. (2015). Communication and Graphic Design (10th Ed.), Dost Publishing House: Ankara.

Beyoğlu, A., \& Ergin, D. Y. (2018). Metaphorical Perceptions of Students in Fine Arts Education Departments on The Concept of Location. Humanitas, 6(11), 71-90.

Büyüköztürk, Ş., Çakmak, E. K., Akgün, Ö. E., Karadeniz, Ş., \& Demirel, F. (2011). Scientific Research Methods (8th Ed.). Ankara: Pegem Publishing House

Çaydere, O. (2016). Life-Long Learning and Graphic Design. International Journal of Human Sciences, 13(1), 787-797. https://doi.org/10.14687/ijhs.v13i1.3535

Dokuzlar, B. K. (2015). Graphic Design For Socially Awareness, SDU ART-E Art Journal of Fine Arts Faculty, Nov/Dec, 8(6).

Gafuroğulları, D. (2014). Graphic Design Advertising Posters of Use: Turkish State Railways Sample. The Turkish Online Journal of Design, Artand Communication-TOJDAC April 2014, 4(2), 53-71. 
https://doi.org/10.7456/10402100/004

Geçit, Y., \& Gençer, G. (2011). Determining The Geographical Perception of the 1st. Grade Students in the Department of Primary Education Through Metaphor (Example of Rize University) Marmara Geographical Review, 23, 1-19.

Hembree, R. (2011). The Complete Graphic Designer. Beverly Massachusetts, USA: Rockport Publishers

Kanat, S., \& Mutlu, H. S. (2017). The Contributions of Ceramic Art Education to the Medical Students, The Journal of International Social Research. 10(51), 729-736. https://doi.org/10.17719/jisr.2017.1809

Kelleci, D. (2014). An Examination into Perceptions of Preservice Classroom Teachers in Relation to Notıon of Climate via Metaphor (Master's Thesis). Giresun University The Institute of Social Sciences, Giresun.

Ketenci, H. F., \& Bilgili, C. (2006). 10000 Years of Mysterious Dance of Chips Visual Communication \& Graphic Design. Istanbul: Beta Publishing House

Landa, R. (2014). Graphic Design Solutions (5th Ed.) Development Editor: Ashley Bargende, Wadsworth Cengage learning: Publisher: Clark Baxter,

McCarthy, S., \& Almeida, C. M. (2002). Self-Authored Graphic Design: A Strategy for Integrative Studies, The Journal of Aesthetic Education, 36(3) (Autumn), 103-116.

Özgün, B. B., Gürkan, G., \& Kahraman, S. (2018). The Investigation of Preservice Teachers' Perception about Scienceand Scientist via Metaphoric Analysis, Inönü University, Journal of the Faculty of Education, 19(2), 204-225.

Pektaş, M., \& Kıldan, A. O. (2009). A Comparison of "Teacher" Metaphores Generated by Preservice Teachers from Different Majors, Erzincan University Journal of Education Faculty, 11(2), 271-287.

Persich, M. R., Steinemann B., Fetterman, A. K., \& Robinson, M. D. (2018). Drawn to the Light: Predicting Religiosity Using “God Is Light” Metaphor. American Psychological Association, 1-11. https://doi.org/10.1037/rel0000216

Saban, A., Koçbeker, B. N., \& Saban, A. (2006). An Investigation of the Concept of Teacher Among Prospective Teachers through Metaphor Analysis, Educational Sciences: Theory \& Practice, 6(2), 509-522.

Shuell, T. J. (1990). Teaching and learning as problem solving. Theory into Practice, 29(2), 102-108. https://doi.org/10.1080/00405849009543439

Triggs, T. (2011). Graphic Design History: Past, Presentand Future. Design Issues, 27(1), 3-6. https://doi.org/10.1162/DESI_a_00051

Twemlow, A. (2011). What is Graphic Design For (2nd Ed.). YEM Publishing House Istanbul.

Ünalan, H. T. (2005). The Effectiveness of Computer Aided Education in Graphic Education in Faculty of Education Department of Fine Arts Education, at Anadolu University (Unpublished PhD's thesis). Anadolu University Graduate School of Educational Sciences, August, Eskişehir.

Uslu, Y. (2017). Excellence and Imperfection Posters in Graphic Design. Bursa: Ekin Publishing House

Yıldırım, A., \& Şimşek, H. (2011). Qualitative Research Methods in the Social Sciences (8th Ed.) Ankara: Seçkin Publishing House

Y1ldiz, S. (2014). Investigation of Faculty Members' Perception About University, Profession of Acedemician, Scientific Research, Teaching and Student Concepts Via Methopors (Master's Thesis), Mersin University Graduate School of Educational Sciences, Mersin.

Yob, I. M. (2003). Thinking constructively with metaphors. Studies in Philosophy and Education, 22, 127-138. https://doi.org/10.1023/A:1022289113443

Yüceil, H. M. (2015). Metaphorical Perception on the Concept of "Woman" of University Students: Ondokuz Mayls University Sample (Master's Thesis). Ondokuz Mays University, Institute of Social Sciences Department of Women and Family Studies, Samsun.

\section{Copyrights}

Copyright for this article is retained by the author(s), with first publication rights granted to the journal.

This is an open-access article distributed under the terms and conditions of the Creative Commons Attribution license which permits unrestricted use, distribution, and reproduction in any medium, provided the original work is properly cited. 